\title{
Teknik Reinforcement Positif untuk Meningkatkan Kemampuan Interaksi Sosial pada Kasus Skizofrenia
}

\author{
Maftuhah $^{1}$, IGAA Noviekayati ${ }^{2}$ \\ 1,2Fakultas Psikologi, Universitas 17 Agustus 1945 Surabaya; Jl. Semolowaru No 45 Menur \\ Pumpungan, (031) 5931800 \\ e-mail: 1'maf.tucha211@gmail.com, ㄹekayatinovi@gmail.com
}

Article History:

Received

$11-09-2020$

Review

$28-11-2020$

Revised

$04-11-2020$

Accepted

$29-11-2020$

Published

$10-12-2020$
Abstract. Schizophrenia is a collection of symptoms in the form of disturbance of thoughts and forms of thought, perception, difficulty thinking properly, understanding and accepting reality, emotions / feelings, behavior and interpersonal relationships.this study investigate positive reinforcement technique to improve social interaction skill in skizophrenic patient. The subject is a man, 39 years old, diagnosed with skizophrenia. Subject has difficulties to interact with other people because unpleasant experience in the past. The research method used is qualitative with an experimental approach. The experimental research design used in this study is the Single Subject Research (SSR) with a single subject type (single cubject design). Retrieval of data using psychological tests and observations. The data analysis used was descriptive analysis in the form of visual graphic analysis. The results showed that there was a positive effect of using positive reinforcement techniques on the ability of social interaction as indicated by overlapping data in the analysis between conditions $A 1 / B$ and $B / A 2$ at $0 \%$, which means that the smaller the percentage of overlap, the greater the effect on target behavior. This is also supported by an increase in the average score of social interaction abilities obtained during the baseline-1, intervention, and baseline-2 phases, namely 1.3 increasing to 7 and increasing again to 10.

Keywords: Positive reinforcement, social interaction, Schizophrenia

Abstrak. Skizofrenia merupakan kumpulan gejala berupa gangguan isi dan bentuk pikiran, persepsi, kesulitan berfikir dengan benar, memahami dan menerima realita, emosi/perasaan, perilaku dan hubungan interpersonal. Studi ini meneliti teknik reinforcement positif untuk meningkatkan kemampuan interaksi sosial pada pasien skizofrenia. Subjek dalam penelitian ini adalah seorang laki-laki berumur 39 tahun didiagnosis gangguan skizofrenia. Subjek mengalami kesulitan untuk berinteraksi dengan orang lain disebabkan pengalaman tidak menyenangkan yang dialami subjek. Metode penelitian yang digunakan adalah kualitatif dengan pendekatan eksperiman. Desain penelitian eksperimen yang digunakan dalam penelitian ini adalah Single Subject Research (SSR) dengan jenis subjek tunggal (single cubject design). Pengambilan data menggunakan tes psikologi dan observasi. Analisis data yang digunakan yakni analisis deskriptif berupa analisis visual grafik. Hasil penelitian menunjukan adanya pengaruh yang positif penggunaan teknik reinforcement positif terhadap kemampuan interaksi sosial yang ditunjukkan dengan data yang tumpang tindih (overlap) dalam analisis antar kondisi A1/B dan B/A2 sebesar $0 \%$ yang berarti semakin kecil presentase overlap menunjukkan semakin besar pengaruh terhadap target behavior. Hal ini juga didukung dengan adanya peningkatan skor rata-rata kemampuan interaksi sosial yang diperoleh selama fase baseline-1, intervensi, dan baseline-2 yaitu 1,3 meningkat 


\section{Philanthropy Journal of Psychology \\ Volume 4 Nomor 2 (2020), 158-171 \\ ISSN 2580-6076 (Print), ISSN 2580-8532 (Online)}

menjadi 7 dan meningkat lagi menjadi 10.

Kata kunci: Reinforcement positif, Interaksi sosial, skizofrenia

\section{Pendahuluan}

Skizofrenia adalah gangguan mental berat dan perjalanan penyakitnya bersifat kronis atau bertahan dalam jangka waktu lama (Fitriani, 2013). Gangguan ini bisa muncul dari akhir masa remaja atau dewasa muda. Skizofrenia adalah gangguan jiwa psikotik yang menimbulkan gejala kejiwaan, seperti kekacauan dalam berpikir, emosi, persepsi, dan perilaku menyimpang, dengan gejala utama berupa waham (keyakinan salah), delusi (pandangan yang tidak benar), dan halusinasi yaitu persepsi tanpa ada rangsang pancaindra (Pairan et al., 2018).

Interaksi sosial merupakan proses utama yang harus dijalani individu dalam kehidupan sosial. Skizofrenia sering mengalami masalah dalam hal bersosialisasi dikarenakan adanya difisit sosial sehingga membuat interaksi sosialnya menjadi terbatas. Adapun gejala skizofrenia menurut Videback terbagi atas dua katagori yaitu positif dan negatif (Elfina, 2020). Gejala positif antara lain pembicaraan kacau, delusi, haluninasi, gangguan persepsi dan gangguan kognitif. Gejala negatif (defisit perilaku) mencerminkan tidak adanya minat kemampuan untuk berinteraksi dengan orang lain, sehingga tampak mimik muka yang datar, tanpa emosi dan cenderung tidak peduli dengan orang disekitarnya. Gejala negatif pada skizofrenia menyebabkan klien mengalami gangguan fungsi sosial dan isolasi sosial. Gejala positif dapat dikontrol dengan pengobatan, tetapi gejala negatif seringkali menetap setelah gejala psikotik berkurang dan sering kali gejala negatif menetap sepanjang waktu dan menjadi penghambat utama pemulihan dan perbaikan fungsi dalam kehidupan sehari-hari (Pangesti, 2016).

Selain mengalami kegagalan dalam menjalankan fungsi sosial, pasien skizofrenia juga menghadapi masalah yang berhubungan dengan keterampilan interpersonal yaitu interaksi sosial yang buruk dan mengalami defisit fungsi kognitif, sehingga mengalami isolasi sosial dan memiliki kualitas hidup yang buruk. Masalah yang dihadapi penderita isolasi sosial adalah kegagalan individu dalam melakukan interaksi dengan orang lain sebagai akibat dari pikiran negatif dan pengalaman yang tidak menyenangkan sebagai ancaman terhadap individu serta mengalami kesulitan melakukan berbagai perasaan dengan orang lain (Harkomah et al., 2018). Akibat interaksi sosial terganggu pada pasien skizofrenia yang tidak segera diketahui dan ditangani berdampak pada pengasingan diri, resiko bunuh diri serta proses pemulihan yang lebih lama (Safitri, 2010).

Degnan dalam (Kurniasari, 2019) menjelaskan bahwa interaksi sosial yang dinamis dan positif dapat meningkatkan kesehehatan mental dan kualitas hidup seseorang. Interaksi sosial memiliki peranan yang sangat penting dalam kesembuhan pasien dengan gangguan skizofrenia. Seseorang yang mampu berinteraksi sosial akan memiliki pola pikir yang positif dan akan 
bereaksi secara adaptif dalam menghadapi masalah atau situasai sulit dalam setiap fase hidupnya (Nyumirah, 2013).

Berdasarkan hasil observasi yang dilakukan di Rumah Sakit Jiwa Menur pasien skizofrenia menunjukkan sulit berinteraksi dengan pasien lain atau perawat yang berjaga. Mereka lebih memilih berdiam diri, ada juga yang meracau (berbicara sendiri). Hasil wawancara dengan seorang pasien yang menyendiri, pasien mengaku dibawa ke rumah sakit karena memukul orang tuanya hingga memar. Setelah dikonfirmasi dengan keluarga dan psikiater yang merawat, pasien sering mengalami halusinasi baik visual dan auditori. Selain itu pasien mengaku sulit tidur, suka mondar-mandiri dan marah-marah serta mengalami penurunan merawat diri seperti jarang mandi.

Interaksi sosial menurut Gillin dan Gillin adalah hubungan-hubungan sosial yang dinamis yang menyangkut hubungan antara individu dengan individu, kelompok dengan kelompok, ataupun individu dengan kelompok (Soekanto, 2010). Pengertian lainnya dikemukan oleh Macionis, dengan bahasa yang lebih sederhana yaitu interaksi sosial merupakan proses dimana orang-orang beraksi dan bereaksi satu sama lain dalam suatu relasi atau hubungan.

Menurut Selo Soemardjan, pengertian interaksi sosial adalah hubungan timbal balik antara manusia (individu) dengan berbagai segi kehidupan bersama. Interaksi sosial dapat terbentuk jika memenuhi dua syarat yaitu terjadi komunikasi dan kontak sosial. Adapun ciri-ciri interaksi sosial adalah (1) Terdapat pelaku sosial yang lebih dari 1 orang. Proses social interactions hanya dapat terjadi ketika terdapat lebih dari satu orang, (2) Terjadi proses komunikasi antar pelaku sosial dengan memakai simbol-simbol. Komunikasi antar pelaku interaksi dapat dilakukan dengan cara lisan, isyarat, dan gestur tubuh, (3) Terdapat dimensi waktu (masa lampau, kini, masa depan) yang bisa menentukan sifat aksi yang sedang berlangsung. Dengan kata lain proses social interactions pernah terjadi di masa lalu, masa kini, dan juga pada masa yang akan datang, dan (4) Interaksi dilakukan karena ada tujuan-tujuan tertentu yang ingin dicapai.

Dalam proses interaksi sosial, terdapat syarat-syarat yang harus terpenuhi agar interaksi tersebut terjadi. Ada dua syarat utama terjadinya interkasi sosial, yaitu kontak sosial dan komunikasi. Kontak berasal dari bahasa Latin yaitu cum atau con yang artinya bersama-sama, dan tango atau tangere yang artinya menyentuh. Jadi apabila diartikan secara harafiah maka kontak berarti bersama-sama menyentuh. Meskipun secara harafiah diartikan bersama-sama menyentuh, namun pada kenyataannya kontak yang terjadi tidak harus selalu bersentuhan. Kontak sosial terjadi ketika ada aksi dan reaksi antar pihak yang berkontak.

Kontak sosial menurut cara dan tingkatannya terbagi menjadi dua, yaitu kontak sosial primer dan kontak sosial sekunder. Kontak sosial primer adalah kontak sosial yang terjadi 


\section{Philanthropy Journal of Psychology \\ Volume 4 Nomor 2 (2020), 158-171 \\ ISSN 2580-6076 (Print), ISSN 2580-8532 (Online)}

secara langsung bertatap muka, misalnya berbicara, saling menyapa, dan bersalaman. Kontak sosial sekunder merupakan kontak sosial yang terjadi melalui suatu perantara. Kontak sosial sekunder pun terbagi menjadi dua, yaitu sekunder langsung dan sekunder tidak langsung. Kontak sosial sekunder langsung terjadi ketika kedua pihak berkontak menggunakan media secara langsung, misalnya bertelepon atau video call.

Bentuk intraksi sosial yang diharapkan adalah interaksi sosial yang positif yang mengarah pada persatuan. Interaksi sosial dapat terlihat dari keterampilan interaksi yang nampak yang menurut Padmavathi, Lalitha \& Pathasarathy dalam (Garvin, 2017) terdiri atas: (1) Memulai pembicaraan dengan orang lain, (2) Mempertahankan pembicaraan dan bertanya, (3) Mempertahankan pembicaraan dengan memberikan informasi faktual, (4) Mempertahankan pembicaraan dengan mengekspresikan perasaan, (5) Mengakhiri pembicaraan, (6) Bergabung dalam sebuah percakapan, (7) Mengikuti topik yang ditentukan orang lain, (8) Melakukan tindakan saat ada yang mengubah topik, (9) Menyatakan pendapat, dan (10) Melakukan sesuatu apabila seseorang tidak memahami ucapan subyek.

Halgin berpendapat bahwa skizofrenia merupakan gangguan dengan jangkauan gejala yang meliputi gangguan terhadap isi pemikiran, bentuk pikiran, persepsi, afeksi, sense of self, motivasi, perilaku, dan keberfungsian interpersonal (Garvin, 2017). Skizofrenia merupakan gangguan otak kronis yang dapat melumpuhkan manusia. Individu dengan gangguan ini dapat mendengar suara-suara yang tidak dapat didengar oleh orang lain. Beberapa diantara mereka yakin bahwa orang lain dapat membaca pikiran mereka, mengontrol pikiran mereka, atau merencanakan sesuatu untuk melukai mereka (Martin \& Pear, 2015). Skizofrenia bukan terjadi karena kepribadian yang terpisah-pisah, melainkan terpecahnya pikiran dengan realita, disertai dengan gejala psikosis seperti kondisi mental yang terdistorsi serta kemampuannya untuk berfungsi pada berbagai area kehidupan. Banyak penderita skizofrenia kehilangan motivasi untuk mengurus dirinya sendiri seperti tidak mau mandi, berhenti bekerja dan menolak untuk berinteraksi dengan orang lain (Sari, 2016).

Penyebab seseorang mengalami skizofrenia diantaranya adalah predisposisi genetik, abnormalitas pada struktur otak dan saraf pengantar, masah prenatal dan komplikasi pada proses kelahiran. Individu yang memiliki keluarga yang terkena skizofrenia akan semakin tinggi pula kemungkinan ia mengidap skizofrenia. Kerentanan biologis yang ada pada seseorang menunggu terjadinya peristiwa-peristiwa dalam hidup atau penyebab stress dari luar dirinya sebagai pemicu utama dari penyakit skizofrenia (Pinel, 2009). Sebagian orang mewarisi potensi untuk mengidap skizofrenia, ditambah dengan kerentanan gen yang disertai dengan pengalaman-pengalaman dan perjalanan hidup seperti stress, traumathic dapat memicu penyakit skizofrenia dengan mudah. Gangguan skizofrenia yang terjadi pada kerabat dekat 
seperti ayah, ibu, anak atau saudara kandung meningkatkan kemungkinan terjadinya skizofrenia pada individu yang bersangkutan. Seseorang dapat menderita skizofrenia karena berbagai faktor. Faktor-faktor tersebut antara lain masalah pada unsur kimia di otak, pengalaman traumatis seperti cita-cita yang tidak tercapai, kehilangan orang yang dicintai, kehilangan pekerjaan, orang tua galak/pola asuh otoriter, dan mendapat perilaku kekerasan (Kurnia, 2016).

Teknik yang dapat digunakan untuk merubah perilaku pasien skizofrenia agar dapat berinteraksi sosial adalah teknik behavioural dengan metode reinforcement positif. Teknik behavioral penerapan dari operant conditioning. Menurut teori belajar Skinner, sebagian besar perilaku manusia adalah perilaku operan yang tidak otomatis, dapat diprediksi, atau terkait dengan setiap cara yang dikenal dengan mudah diidentifikasi oleh rangsangan. Skinner percaya bahwa konsekuensi membentuk semua perilaku, termasuk perilaku yang dilabeli abnormal. Skinner membagi penguatan menjadi dua, yaitu penguatan positif dan penguatan negatif. Penguatan positif sebagai stimulus dapat mengakibatkan terjadinya pengulangan tingkah laku itu sedangkan penguatan negatif dapat mengakibatkan perilaku berkurang atau menghilang. Reward merupakan penguatan positif (reinforcement) yang diberikan untuk meningkatkan perilaku yang diinginkan. Sedangkan punishment diberikan sebagai konsekuensi dari perilaku. Penguat positif adalah sebuah kejadian yang apabila disajikan langsung mengikuti sebuah perilaku, menyebabkan perilaku tersebut meningkat (Sari, 2016).

Terdapat tiga jenis reinforcement yang dapat digunakan untuk modifikasi tingkah laku, yaitu (1) Primary reinforce atau uncondition reinforce, yaitu reinforcement yang langsung dapat dinikmati misalnya makanan dan minuman. (2) Secondary reinforce atau conditioned reinforce. Pada umunya tingkah laku manusia berhubungan dengan ini, misalnya uang, senyuman, pujian, medali, pin, hadiah dan kehormatan. (3) Contingency reinforcement, yaitu tingkah laku tidak menyenangkan diapakai sebagai syarat agar anak melakukan tingkah laku menyenangkan (Corey, 2010). Adapun langkah-langkah penerapan reinforcement positif adalah sebagai berikut : (a) Mengumpulkan informasi tentang permasalahan melalui analisis ABC, (b) Memilih perilaku target yang ingin ditingkatkan, (c) Menetapkan data awal (baseline) perilaku awal, (d) Menentukan reinforcement yang bermakna, (e) Menetapkan jadwal pemberian reinforcement, dan (f) Penerapan reinforcement positif.

Untuk dapat kembali bermasyarakat, pasien skizofrenia setidaknya sudah mampu berkomunikasi atau menjalin interaksi sosial dengan orang di lingkungannya diperlukan terapi untuk merubah perilaku pasien skizofrenia yang awalnya melakukan isolasi sosial menjadi interaksi sosial. Hal ini didukung oleh penelitian yang dilakukan (Anityo et al., 2013) yang 
mengungkapkan bahwa adanya interaksi yang aktif selama selama perawatan dengan pemberian terapi dapat meningkatkan partisipasi positif pada pasien skizofrenia.

Kemampuan interaksi skizofrenia dapat ditingkatkan dengan merubah perilaku yaitu dengan teknik behaviour dan menerapkan metode reinforcement positif. Positive Reinforcement yaitu memberikan konsekuensi yang menyenangkan saat suatu perilaku yang diharapkan muncul dengan tujuan agar perilaku tersebut dilakukan lagi secara konsisten. Teknik ini dirasa efektif karena pasien akan tertarik untuk melakukan perubahan perilaku dengan perasaan yang menyenangkan. Berbeda dengan teknik perilaku yang memberikan punishment, dimana seseorang yang tidak dapat menunjukkan perilaku yang diharapkan akan mendapat hukuman. Teknik reinforcement negative akan membuat seseorang melakukan sesuatu karena perasaan tertekan dan ketakutan. Dengan teknik Positive Reinforcement pasien skizofrenia diharapkan mampu mambangun interaksi social yang lebih aktif.

Penelitian sebelumnya yang dilakukan oleh Mutia Pangesti (2016) pada pasien skizofrenia berumur 31 tahun yang mengalami kesulitan untuk berinteraksi dengan orang lain disebabkan pengalaman tidak menyenangkan yang dialami. Setelah dilakukan intervensi dengan konseling behavior dan pemberian pelatihan keterampilan sosial sebanyak tujuh sesi, memperlihatkan dampak positif pada diri subjek. Hal ini terlihat dari perubahan perilaku subjek yang sudah dapat menyapa, berkenalan, dan berbicara dengan orang lain.

Berdasarkan uraian tersebut, peneliti tertarik untuk melakukan penelitian dengan teknik reinforcement positif sebagai media untuk meningkatkan kemampuan interaksi sosial pada pasien skizofrenia.

Penelitian ini bertujuan untuk mengetahui peningkatan kemampuan interaksi sosial melalui teknik reinforcement positif pada kasus skizofrenia

\section{Metode}

Subyek dalam penelitian ini adalah seorang laki-laki berusia 39 tahun pasien skizofrenia RSJ Menur Surabaya. selain itu juga terdapat informan yaitu orang tua dan psikiatri yang juga akan bertindak sebagai signifikan other dalam pelaksanaan intervensi.

Penelitian ini menggunakan metode kualitatif yang berorientasi pada fenomena atau gejala yang terjadi di sekitar lingkungan. Pendekatan yang digunakan adalah pendekatan eksperimen yang bertujuan untuk mencari kondisi tertentu setelah diberikan pengaruh dalam kondisi yang terkendalikan (Sugiyono, 2015). Peneliti akan menggali informasi secara mendalam dan memusatkan diri secara intensif tentang pembentukan perilaku untuk meningkatkan interaksi sosial pada klien skizofrenia. Desain penelitian eksperimen yang digunakan dalam penelitian ini adalah Single Subject Research (SSR) dengan jenis subjek tunggal 
Philanthropy Journal of Psychology

Volume 4 Nomor 2 (2020), 158-171

ISSN 2580-6076 (Print), ISSN 2580-8532 (Online)

(single cubject design). Desain subjek tunggal memfokuskan pada data individu sebagai sampel penelitian.

Desain penelitian yang digunakan adalah pola A-B-A yang merupakan pengembangan dari desain dasar A-B. Desain A-B-A ini menunjukkan adanya hubungan sebab akibat antara variabel terikat dan variabel bebas.

\section{Bagan 1. Rancangan Penelitian}

Baseline $1 \longrightarrow$ Intervensi atau pengukuran $\longrightarrow$ Baseline 2

Mula-mula target behavior diukur secara kontinu pada kondisi baseline (A1) pada periode waktu tertentu kemudian diberikan intervensi (B) dan pada kondisi intervensi pengukuran pada baseline kedua (A2) diberikan. Pada dasarnya dalam penelitian Single Subject Research (SSR) dengan desain subjek tunggal, subjek diberlakukan pada keadaan tanpa treatment/intervensi dan dengan treatment/intervensi secara bergantian kemudian target behavior diukur secara berulang-ulang dengan periode waktu tertentu (Sunanto, 2005). Dalam penelitian ini periode waktu pengukuran adalah 2 minggu.

Teknik pengumpulan data dalam penelitian ini menggunakan teknik wawancara, obsevasi dan tes psikologi. Wawancara dilakukan pada subyek, orang tua subyek dan psikiater yang merawat subyek. Observasi dilakukan dengan mengamati subyek yang sedang melakukan aktivitas sebelum diberikan intervensi, saat pelaksanaan intervensi dan sesudah intervensi. Selain itu tindakan orang disekitar subyek saat intervensi juga perlu diperhatikan karena dapat mempengaruhi keberhasilan subyek.

Instrumen penelitian yang digunakan sesuai dengan yang diungkapkan Garvin (2016) dimana interaksi social yang positif tampak dari keterampilan seseorang ketika berinteraksi yaitu kemampuan memulai interaksi social dan kemampuan memberikan respon. Indikator memulai interaksi social dicirikan dengan a) memulai pembicaraan, b) tersenyum saat bertatap muka, c) menyatakan pendapat, d) ikut bergabung dalam percakapan, e) berusaha menjelaskan sesuatu, f) mengajak untuk melakukan aktifitas dan g) memulai tindakan. Sedangkan indicator memberikan respon ketika berinteraksi adalah a) membalas sapaan, b) mempertahankan pembicaraan, c) mengikuti topik yang sudah ditentukan, d) mengakhiri pembicaraan dan e) mengikuti dengan antusias ajakan beraktivitas.

Semua kegiatan yang dilakukan saat sebelum dan sesudah intervensi diobservasi dan dicatat dalam bentuk ceklis keberhasilan atau kegagalan subyek melakukan aktivitas sesuai yang telah ditetapkan. Skala penilaian adalah dengan memberikan nilai 1 pada setiap indicator yang muncul dan 0 pada indicator yang tidak tampak. Data yang diperoleh akan dianalisis 
Philanthropy Journal of Psychology

Volume 4 Nomor 2 (2020), 158-171

ISSN 2580-6076 (Print), ISSN 2580-8532 (Online)

dengan membandingkan kondisi subjek antara sebelum menjalani intervensi dan sesudah intervensi.

Analisis data menggunakan teknik statistic deskriptif yaitu statistik yang digunakan untuk menganalisis data dengan cara mendeskripsikan dan menggambarkan data yang telah terkumpul sebagaimana adanya tanpa bermaksud membuat kesimpulan yang general. Data dapat disajikan dalam bentuk tabel, grafik, diagram lingkaran, pictogram, pengukuran tendensi sentral dan perhitungan presentase. Sedangkan dalam penelitian ini data disajikan dalam bentuk grafik dan table untuk melihat perubahan data pada setiap sesi dan menunjukkan tingkat perilaku interaksi social pada fase baseline dan intervensi.

\section{Hasil}

Pada pelaksanaan intervensi selama 6 hari, hal-hal yang dilaksanakan anatara lain: (a) Melakukan observasi kegiatan yang dilakukan klien selama 60 menit yaitu memperhatikan klien berinteraksi sosial, (b) Melakukan wawancara untuk penguatan intervensi kepada klien selama 30 menit dengan 1) menanyakan tentang kegiatan yang sudah dilakukan berdasarkan hasil observasi, 2) memberikan reward kepada klien setiap klien berhasil melakukan perilaku yang diharapkan, dan 3) mempertahankan perilaku yang diharapkan klien dengan memberi pengertian lebih lanjut tentang keberhasilan atau kegagalan klien agar tetap muncul perilaku yang diharapkan pada hari berikutnya.

Dari data hasil penelitian selama 12 hari, dengan pembagian 3 hari pertama (satu hari 1 sesi selama 45 menit) yang disebut baseline 1, kemudian 6 hari intervensi (satu hari 1 sesi selama 60 menit) dan dievaluasi selama 3 hari (satu hari 1 sesi selama 45 menit) yang dinamakan baseline 2. Adapun tabel hasil penilaian observasi penelitian adalah sebagai berikut:

Tabel 1. Skor Subyek Penelitian

\begin{tabular}{|c|c|c|c|c|c|}
\hline & \multirow[b]{2}{*}{ Sesi } & \multirow[b]{2}{*}{ Tanggal } & \multicolumn{2}{|l|}{ Skor } & \multirow{2}{*}{$\begin{array}{l}\text { Jumlah Skor } \\
\text { interaksi } \\
\text { sosial }\end{array}$} \\
\hline & & & $\begin{array}{l}\text { Memulai } \\
\text { Interaksi }\end{array}$ & $\begin{array}{l}\text { Memberikan } \\
\text { Respon }\end{array}$ & \\
\hline \multirow{3}{*}{ Baseline (A1) } & 1 & 02-Sep-19 & 0 & 1 & 1 \\
\hline & 2 & 03-Sep-19 & 1 & 1 & 2 \\
\hline & 3 & 04-Sep-19 & 0 & 1 & 1 \\
\hline \multirow{6}{*}{ Intervensi (B) } & 4 & 06-Sep-19 & 2 & 3 & 5 \\
\hline & 5 & 09-Sep-19 & 2 & 3 & 5 \\
\hline & 6 & 10-Sep-19 & 4 & 3 & 7 \\
\hline & 7 & 11-Sep-19 & 4 & 3 & 7 \\
\hline & 8 & 12-Sep-19 & 4 & 4 & 8 \\
\hline & 9 & 13-Sep-19 & 5 & 4 & 9 \\
\hline \multirow{3}{*}{ Baseline (A2) } & 10 & 16-Sep-19 & 5 & 5 & 10 \\
\hline & 11 & 17-Sep-19 & 5 & 5 & 10 \\
\hline & 12 & 18-Sep-19 & 6 & 5 & 11 \\
\hline
\end{tabular}


Dari skor penilaian berdasarkan observasi yang telah dilakukan, dapat diketahui bahwa rata-rata skor permulaan kemampuan interaksi sosial subjek pada fase baseline 1 adalaha 1,3. Setelah dilakukan intervensi selama 6 hari rata-rata skor kemampuan interaksi sosial subyek sebesar 7 dan mengalami peningkatan pada fase baseline 2 yaitu skor kemampuan interaksi sosial subyek sebesar 10 yang disajikan dalam grafik sebagai berikut:

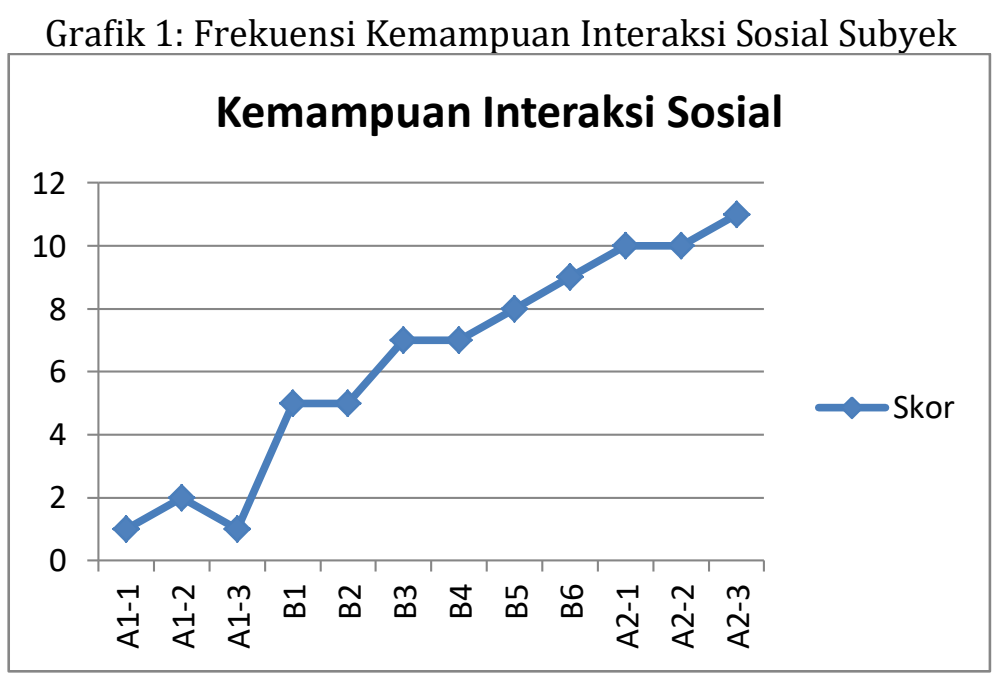

Berdasarkan Grafik 1 dapat diketahui perubahan yang positif kemampuan berinteraksi sosial subyek dari fase baseline awal (A1), intervensi dan fase baseline kedua (A2). Perubahan kecenderungan arah antara kondisi baseline awal (A1) dan intervensi (B) yaitu menaik ( - ) dengan hasil yang lebih baik atau positif. Grafik tersebut juga menunjukkan perubahan kecenderungan arah antara baseline kedua (A2) dan intervensi (B) yaitu menaik ( - ) ke menaik ( $\longrightarrow$ dengan hasil yang lebih baik atau positif. Sedangkan perubahan level data dari fase intervensi (B) ke baseline awal (A1) adalah perubahan yang positif (meningkat) sebesar 4. Perubahan level data dari fase baseline kedua (A2) ke intervensi (B) adalah perubahan yang negatif atau mengalami penurunan sebesar 1. Data yang tumpang tindih (overlap) pada baseline awal ( $\mathrm{A}_{1}$ ) ke intervensi (B) adalah 0\%. Sedangkan data yang tumpang tindih pada fase baseline kedua (A2) ke intervensi (B) yaitu sebesar 0\%. Sehingga hasil analisis data tersebut dapat dirangkum dalam tabel sebagai berikut : 
Tabel 2. Rangkuman Analisis Visual Antar Kondisi dengan Aspek Presentasai Skor Hasil Observasi Kemampuan Interaksi Sosial Subyek

\begin{tabular}{llcc}
\hline No & \multicolumn{1}{c}{ Kondisi } & $\begin{array}{c}\text { B / A1 } \\
\mathbf{( 2 : 1 )}\end{array}$ & $\begin{array}{c}\text { A2 / B } \\
(\mathbf{1 : 2})\end{array}$ \\
\hline 1 & Jumlah variabel yang diubah & 1 & 1 \\
\hline 2 & Perubahan kecenderungan arah efeknya & - & $(+)$ \\
\hline 3 & Perubahan kecenderungan stabilitas data & Variable ke Stabil & Stabil ke Variable \\
& & $5-1=+4$ & $10-9=+1$ \\
\hline 4 & Perubahan level & $\begin{array}{c}(0: 6) \times 100 \% \\
=0 \%\end{array}$ & $\begin{array}{c}(0: 3) \times 100 \% \\
=0 \%\end{array}$ \\
\hline 5 & Presentasi Overlap & &
\end{tabular}

\section{Diskusi}

Hasil penelitian ini menunjukkan bahwa penderita skizofrenia memiliki kesulitan berinteraksi sosial karena kurang mampu memahami perasaan diri serta orang di sekitarnya, tidak ada yang mampu mengerti dirinya dan merasa ditolak oleh lingkungan. Hal ini sesuai dengan yang diungkapkan oleh penelitian sebelumnya bahwa masalah yang sering dihadapi penderita skizofrenia adalah kegagalan individu dalam melakukan interaksi dengan orang lain sebagai akibat dari pikiran negatif dan pengalaman yang tidak menyenangkan sebagai ancaman terhadap individu serta mengalami kesulitan melakukan berbagai perasaan dengan orang lain (Harkomah et al., 2018).

Intervensi terapi perilaku dalam penelitian ini menggunakan teknik reward yang dilakukan dalam 12 sesi yaitu 3 sesi baseline awal (A1), 6 sesi intervensi (B), dan 3 sesi baseline 2 (A2). Hasil dari pemberian intervensi berupa teknik reward pada subyek menunjukkan adanya perubahan atau perbaikan perilaku menjadi lebih stabil dan bertahan seperti yang diharapkan. Reward yang diberikan berupa pujian dan barang, hal yang diinginkan oleh pasien yaitu permen dan pujian sebagai penghargaan atas keberhasilannya melakukan interaksi sosial. Hal ini termasuk dalam kategori social reward, dimana reward didapatkan dengan cara berinteraksi dengan orang lain (Detweiler-Bedel, Detweiler-Bedel, Hazlett, 2008). Intervensi yang diberikan memberikan pemahaman pada subyek bahwa ketika berinteraksi dengan orang di sekitarnya, maka ia akan mendapatkan permen dan mendapatkan teman baru untuk berbicara, hal ini akan tertanam pada dirinya sehingga perilaku interaksi sosial akan terjaga. Hal ini didukung oleh hasil penelitian yang menyebutkan bahwa seseorang akan menghasilkan performa yang bagus ketika mendapatkan reward (Myers, Moustafa, Sheynin, VanMeenen, Gilbertson, et al, 2013). Selain itu, penerapan reward berpengaruh besar pada perubahan perilaku pasien skizofrenia, sebagaimana hasil penelitian Dowd \& Barch (2012) yang menyebutkan bahwa otak merespon reward dengan baik pada individu yang mengalami 
Philanthropy Journal of Psychology

Volume 4 Nomor 2 (2020), 158-171

ISSN 2580-6076 (Print), ISSN 2580-8532 (Online)

skizofrenia kronis.

Berdasarkan hasil analisis data dalam kondisi pada fase baseline-1 diperoleh hasil yaitu estimasi kecenderungan arah dan jejak data menunjukkan peningkatan namun pada level stabilitas rentang masih menunjukkan data yang stabil di setiap sesinya. Kemudian estimasi kecenderungan arah dan jejak data pada fase intervensi dan baseline-2 menunjukkan adanya peningkatan.

Analisis data antar kondisi menunjukkan perubahan kecenderungan arah menaik pada fase baseline-1, intervensi, dan intervensi, baseline-2, sehingga menunjukan bahwa kemampuan interaksi sosial penderita skizofrenia mengalami perubahan setelah diberikan intervensi. Pada kecenderungan stabiltas menujukan kestabilan. Pada intervensi dan baseline-2 kecenderungan stabilitas menunjukkan arah dari variable menuju stabil. Data overlap pada perbandingan B/A1 dan A2/B dengan perolehan 0\%. Dengan hasil tersebut semakin kecil persentase overlap menunjukan bahhwa dugaan semakin efektifnya dilakukan intervensi terhadap target behavior. Pendapat tersebut sependapat dengan Juang Sunanto, dkk (2006: 84) yang menyatakan bahwa "semakin kecil persentase overlap makin baik pengaruh intervensi terhadap target behavior". Dengan hasil tersebut menunjukan bahwa teknik Reinforcement positif efektif meningkatkan kemampuan interaksi sosial penderita skizofrenia.

Berdasarkan hasil penelitian dan intervensi yang telah dilakukan, teknik reinforcement positif yang diterapkan oleh peneliti efektif meningkat kemampuan interaksi sosial pada kasus penderita skizofrenia. Hasil penelitian ini juga didukung oleh penelitian sebelumnya yang dilakukan oleh Padmayana yang menyatakan bahwa penggunaan konseling behavioral teknik penguatan positif lebih evektif daripada perlakuan konvensional untuk meningkatkan perilaku sosial (Padmayana et al., 2014). Reward yang diberikan khususnya dari caregiver sangat berpengaruh besar dalam kesembuhan klien, caregiver yang baik dan dpat diandalkan merupakan salah satu hal yang sangat dibutuhkan pasien skizofrenia. Hal ini didukung oleh penelitian yang menyebutkan bahwa pengalaman positif yang didapatkan dari berinteraksi dengan orang lain dapat memberikan perasaaan menyenangkan bagi pasien maupun caregiver tersebut ( Chen \& Greenberg, 2004).

Untuk lebih memperkuat intervensi yang diberikan, peneliti juga memberikan edukasi kepada keluarga agar tetap memotivasi untuk kesembuhan subyek dengan menjaga rutinitas pemberian obat dan kontrol ke rumah sakit. Selain itu peneliti memberikan gambaran pentingnya keterlibatan orang tua dalam membangun komunikasi yang efektif dengan subyek baik dengan mengajak subyek berbicara tentang aktivitas sehari-hari ataupun menanyakan perasaan subyek sebagaimana yang dilakukan saat intervensi. Sehingga subyek dapat lebih terbuka tentang apa yang dirasakan kepada keluarganya. Keluarga sangat berperan terhadap 
Philanthropy Journal of Psychology

Volume 4 Nomor 2 (2020), 158-171

ISSN 2580-6076 (Print), ISSN 2580-8532 (Online)

tingkat interaksi sosial pasien Skizofrenia, hal tersebut didukung dengan adanya hasil penelitian sebelumnya (Fitriatun, 2019) bahwa peran keluarga dalam memenuhi kebutuhan asah, asih, asuh dengan cukup, dapat diikuti dengan tingkat interaksi pasien juga cukup.

Interaksi sosial bermasyarakat bagi subyek dapat membantu dalam meningkatkan hubungan sosial di lingkungan sekitar rumah, sekolah, maupun tempat kerja. Interaksi sosial adalah hubungan antar manusia dan interaksi positif hanya mungkin terjadi apabila terdapat suasana saling mempercayai, menghargai, dan saling mendukung. Maka dari itu jika klien Skizofrenia mampu berinteraksi secara baik maka akan bermanfaat bagi diri sendiri ataupun orang lain.

\section{Simpulan}

Penderita skizofrenia mengalami kesulitan dalam berinteraksi dan membangun komunikasi efektif dengan orang-orang disekitarnya karena merasa ditolak oleh lingkungan sehingga menarik diri dari lingkungan sosial. Kemampuan interaksi sosial penderita skizofrenia meningkat setelah diberikan terapi dengan teknik reinforcement positif kecenderungan stabilitas menunjukkan arah dari variable menuju stabil. Data overlap pada perbandingan B/A1 dan A2/B dengan perolehan $0 \%$. Dengan hasil tersebut semakin kecil persentase overlap menunjukan bahhwa dugaan semakin efektifnya dilakukan intervensi terhadap target behavior. Intervensi dilakukan dengan metode behavior terapi dengan teknik reinforcement positif dengan tujuan merubah perilaku subyek yang semula menarik diri dari lingkungan sosial menjadi lebih terbuka dalam menjalin interaksi sosial. Intervensi dilakukan dalam 12 sesi yang sudah ditetapkan dengan waktu tertentu. Pada sesi intervensi diberikan perlakuan selama 6 hari dan diobservasi hasilnya. Hasil intervensi menunjukkan terdapat perubahan pada diri subyek yang semula menarik diri menjadi mau berbaur, merespon dan melakukan interaksi sosial.

Berdasarkan hasil dari penelitian yang telah dilakukan, peneliti memberikan saran (1) bagi penderita skizofrenia agar tetap melakukan interaksi sosial dengan orang-orang sekitar sehingga dapat mengurangi pikiran negatif yang muncul. (2) bagi keluarga diharapkan senantiasa mengajak berkomunikasi dengan menanyakan perasaan dan kegiatan yang dilakukan penderita skizofrenia sehingga membuat mereka lebih mudah mengungkapkan perasaan dan permasalahan yang dihadapi kepada keluarga dan mengurangi terjadinya isolasi sosial (3) bagi peneliti selanjutnya agar dapat melanjutkan penelitian serupa dengan mempertimbangkan aspek lain yang mempengaruhi interaksi sosial pada penderita skizofrenia seperti dukungan sosial dari keluarga yang belum detil dikakukan dalam penelitian ini sehingga dapat menjadi rujukan dalam mengatasi masalah serupa. 


\section{Kepustakaan}

Anityo, Giri K, P., \& Munawar, N. H. (2013). Pengaruh Terapi Kognitif Terhadap Kemampuan Berinteraksi Pasien Skizofrenia Dengan Isolasi Sosial di RSJ Grhasia Yogyakarta (pp. 297305).

Corey, Gerald. 2010. Teori dan Praktek Konseling Psikoterapi. Bandung : PT Refika Aditama.

Elfina, M. L. (2020). Latihan keterampilan sosial untuk meningkatkan kemampuan interaksi sosial pada pasien skizofrenia. Procedia : Studi Kasus Dan Intervensi Psikologi, 7(2), 74-84. https://doi.org/10.22219/procedia.v7i2.13025

Fitriani, A. (2013). Psikoterapi Suportif pada Penderita Skizofrenia Hebefrenik. Journal of Chemical Information and Modeling, 53(9), 1689-1699. https://doi.org/10.1017/CB09781107415324.004

Fitriatun, E. (2019). Peran Keluarga Dalam PEeningkatan Kemampuan Interaksi Sosial Bermasyarakat Klien Skizofrenia Pasca Perawatan Di Rumah Sakit. Journal of Chemical Information and Modeling, 53(9), 1689-1699. https://doi.org/10.1017/CB09781107415324.004

Garvin, G. (2017). Efektivitas Group Behavior Therapy Terhadap Conversational Skill Pada Pasien Skizofrenia Tipe Residual (Studi Kasus Pada Instansi X). Psibernetika, 9(2). https://doi.org/10.30813/psibernetika.v9i2.469

Harkomah, I., Arif, Y., \& Basmanelly. (2018). Pengaruh Terapi Social Skills Training ( Sst) Dan Terapi Suportif Terhadap Keterampilan. 02(01), 61-65. https://doi.org/ISSN 2549-2721, ISSN 2549-2748 (Online)

Kurnia, S. I. M. R. (2016). Identifikasi Penyebab Skizofrenia: Studi Kasus di Kabupaten Trenggalek. Peneliti Muda Psikologi Indonesia, 1(1), 9-17. https://doi.org/10.1017/CB09781107415324.004

Kurniasari, C. I. ; M. D. S. P. S. (2019). Social Interaction on Patients with Schizophrenia in Psychiatric Hospital. 15(2), 25-30. https://doi.org/10.26753/jikk.v15i2.335

Nyumirah, S. (2013). Peningkatan Kemampuan Interaksi Sosial (Kognitif, Afektif Dan Perilaku) Melalui Penerapan Terapi Perilaku Kognitif Di Rsj Dr Amino Gondohutomo Semarang. Keperawatan Jiwa, 2, 121-128. http://pmb.stikestelogorejo.ac.id/ejournal/index.php/ilmukeperawatan/article/view/45

Padmayana, I. G. B. A. P., Suarni, N. K., Putri, D. A. W. M., \& Ps, S. (2014). Pengaruh Konseling Behavioral Dengan Teknik Penguatan Positif Untuk Meningkatkan Perilaku Sosial Siswa Kelas VII SMP Negeri 2 Singaraja Tahun Pelajaran 2013/2014. Jurnal Ilmiah Bimbingan Konseling Undiksha, 2(1).

Pairan, Mubarok, A. M., \& Nugraha, E. N. (2018). Metode Penyembuhan Penderita Skizofrenia oleh Mantri dalam Perspektif Pekerjaan Sosial. EMPATI: Jurnal Ilmu Kesejahteraan Sosial, 7(1), 63-76. https://doi.org/10.15408/empati.v7i1.10015

Pangesti, M. (2016). Konseling Behavior dan Pelatihan Keterampilan Sosial untuk Meningkatkan Interaksi Sosial pada Pasien Skizofrenia. Psychology Forum UMM, 291-296.

Sari, G. D. (2016). Penerapan Reward dan Punishment untuk Meningkatkan Perilaku Rutin Minum 
Philanthropy Journal of Psychology

Volume 4 Nomor 2 (2020), 158-171

ISSN 2580-6076 (Print), ISSN 2580-8532 (Online)

Obat pada Pasien Skizofrenia. 19-20.

Seikanto, Soerjono. (2010). Sosiologi Suatu Pengantar. Jakarta: PT Raja Grafindo Persada

Sugiyono. (2015). Metode Penelitian Pendidikan (Pendekatan Kuantitatif, Kualitatif, dan R\&D).

Bandung: Alfabeta

Sunanto, Juang. (2005). Pengantar Penelitian dengan Subyek Tunggal. CRICED University of Tsukuba 